\title{
FLORISTIC STRUCTURE AND VEGETATION DIVERSITY OF THE WADI OTHYLAN PROTECTED AREA IN SAUDI ARABIA
}

\author{
AlsAlEM, A. A. ${ }^{*}$ - Alfarhan, A. A. ${ }^{1}-$ El-SHEIKH, M. A. ${ }^{1,2}$ \\ ${ }^{1}$ Department of Botany \& Microbiology, College of Science, King Saud University, P.O. Box \\ 2455, Riyadh 11451, Saudi Arabia \\ ${ }^{2}$ Botany Department, Faculty of Science, Damanhour University, Damanhour, Egypt \\ ${ }^{*}$ Corresponding author \\ e-mail: abdullah.alsalem.ksu@gmail.com \\ (Received $7^{\text {th }}$ Jul 2020; accepted $7^{\text {th }}$ Oct 2020)
}

\begin{abstract}
Wadi Othylan is one of the most important protected areas in the central region of Saudi Arabia supporting a high level of plant diversity. The current study aims to examine the vegetation and floristic diversity of wadi Othylan protected area and the relation between such diversity and soil characteristics. A total of 78 plant species belonging to 69 genera distributed among 27 families were collected from the studied stands. TWINSPAN, and detrended correspondence analysis (DCA) analyses classified the plant cover data into the following four plant communities: VG I: Fagonia bruguieri-Haloxylon salicornicum, VG II: Acacia ehrenbergiana-Echinops spinosissima, VG III: Acacia ehrenbergiana-Acacia gerardii and VG IV: Acacia ehrenbergiana-Calotropis procera. Plant species present in wadi Othylan may be an indicator for the low human impact on this area. A significant variation in soil texture, $\mathrm{pH}, \mathrm{EC}$ and organic matter and mineral contents were observed which was correlated with different vegetation groups.
\end{abstract}

Keywords: soil characteristics, TWINSPAN, organic matter, $p H, E C$

\section{Introduction}

Wadi Othylan is a protected area located in Al-Kharj in the central region of Saudi Arabia. The central region of Saudi Arabia is characterized by highly diverse terrain ranging from small mountains to desert plains including hillocks and plateaus (Alfarhan, 2001; Shaltout and Mady, 1996). This area belongs to the Saharo-Arabian phytogeographical zone (Alatar et al., 2012). The wadi (valley) ecosystems are considered as one of the most important plant diversity centers in the central region of Saudi Arabia; however, there has been great lack of the studies considering floristic structure and vegetation diversity of these ecosystems until now (Chaudhary, 2001; Alatar et al., 2012). Furthermore, wadi ecosystems are significant for socioeconomic development considering their ecological importance for environmental gradients and physiographic variation.

The central region of Saudi Arabia is characterized by high plant diversity; more than 600 plant species are reported in the central region out of 2,243 plant species in the whole country (Collenette, 1985, 1998, 1999; Chaudhary, 2001). Several studies have been conducted to examine the vegetation of the central region including studies concerning wadi ecosystems e.g. Wadi Al-Jufair (Alatar et al., 2012) and Wadi Hanifa (Taia and ElGhanem, 2001; El-Ghanim et al., 2010). Other studies examined the vegetation diversity of different protected areas in Saudi Arabia including Harrat Al-Harrah (El-Sheikh et al., 2019), Huraimla (Alatar et al., 2015), and Thumamah Nature Park (El-Sheikh et al., 2013). However, the present study is the first to examine the vegetation of wadi Othylan protected area, Saudi Arabia. 
The majority of soils of the natural habitats in the central region of Saudi Arabia are classified among Aridisols with very low amount or without any accumulation of organic matter and clay (Al-Nafie, 2008). On the other hand, soils in wadi basin are deep with fine texture and mixed with different sizes of rocks supporting the growth of different vegetation (Batanouny, 1987). Since wadi Othylan is one of the most important wadi habitats in the central region of Saudi Arabia and the richest wadis in vegetation and floristic diversity as it is one of the protected areas. We conducted this study aiming to examine the vegetation and floristic diversity of wadi Othylan protected area and the relation between such diversity and soil characteristics.

\section{Materials and methods}

\section{Study area}

Wadi Othylan $\left(23^{\circ} 785.702^{\prime} \mathrm{N}\right.$ and $\left.46^{\circ} 926.531^{\prime} \mathrm{E}\right)$ is one of the most important wadis in Al-Kharj area in the central region of Saudi Arabia. It is located about $90 \mathrm{~km}$ southern Riyadh, the capital city of Saudi Arabia, with an altitude about $519 \mathrm{~m}$ above sea level with a total size of approximately $45 \mathrm{~km}^{2}(15 \mathrm{~km} \times 3 \mathrm{~km})$. It is characterized by its high diverse vegetation ranged from trees to shrubs, perennials and annual plants. Wadi Othylan was considered as a protected area and national park in Saudi Arabia on 1982. The study area is considered as one of the main features of the large plateau located in the central region of Saudi Arabia known as "Najd". This area is characterized mainly by distribution of large wadis emerging from the western mountains toward the eastern region of Najd; however, the majority of these wadis are not continuous as they covered by the sand dunes of Dahna desert. During winter rainy days, seasonal springs emerge in these wadis forming shallow pools characterized by high plant diversity. It is thought that these areas had a wetter climate in the past as remnants of their vegetation could be found along their stretch (Al-Nafie, 2008).

Plant biodiversity in wadi Othylan is significantly affected by topography factors as the area examined in this study could be separated into three different habitats i.e. depressions, rocky hills and sand dunes. Wadi Othylan is generally characterized by harsh environment; however, a great biodiversity could be found among different habitats forming the ecosystem of this wadi. In general, the dominant plant life forms during winter season are trees, shrubs and annual herbs classified mainly as mesophytes and representing different plant communities.

The study area could be separated into three different physiographical parts i.e. wadi bed, slope and plateau. The wadi bed (basin) is generally characterized by low sand dunes. On the other hand, plateau is dominated by shallow drainage runnels and notches due to the flat rocky surfaces with little amount of soil distributed among them. The slope is separated into top, middle and lower parts. The upper parts are very steep without any soil cover supporting only cliff vegetation. The middle parts are less steep than the upper parts covered with a mix of different sizes of rocks and shallow soil supporting vegetation different types of vegetation mainly chasmophytic shrubs and grasses. The lower parts are characterized by deep soil accumulated by run-off water and high vegetation density.

Meteorological data of the study area shows that it is characterized by hot dry weather in the summer and cold weather in the winter. Average maximum air temperature ranges from $20.3{ }^{\circ} \mathrm{C}$ in January and $44{ }^{\circ} \mathrm{C}$ in July, while the minimum air temperature ranges from $7{ }^{\circ} \mathrm{C}$ in January and $30^{\circ} \mathrm{C}$ in July and August. The annual rainfall in the study area ranges from 2 to $22 \mathrm{~mm}$. The mean wind speed ranges from 4 to $7 \mathrm{~km} / \mathrm{h}$. The average 
relative humidity is $49 \%$ with lowest values occurs in June and July $(11-12 \%)$. The average evaporation value is around $10.35 \mathrm{~mm} /$ day (Al-Nafie, 2008).

\section{Sample stands}

A total of 20 study stands were selected to represent different habitats in the study site. Each stand area was $2500 \mathrm{~m}^{2}(50 \mathrm{~m} \times 50 \mathrm{~m})$. Figure 1 shows the study area with the location of the selected sample stands. Collection of samples was performed in the spring season as the majority of the species expected to exist. To analyze the vegetation of the study area, all plants collected from the different stands were identified and classified. Plant species, chorotypes and life forms (Shelter and Skog, 1978) were recorded. Identification of plant species depends mainly on the available references regarding the vegetation of Saudi Arabia (Collenette, 1985, 1998, 1999; Chaudhary, 2001). The line intercept method was used to calculate the plant cover parameters (Canfield, 1941).

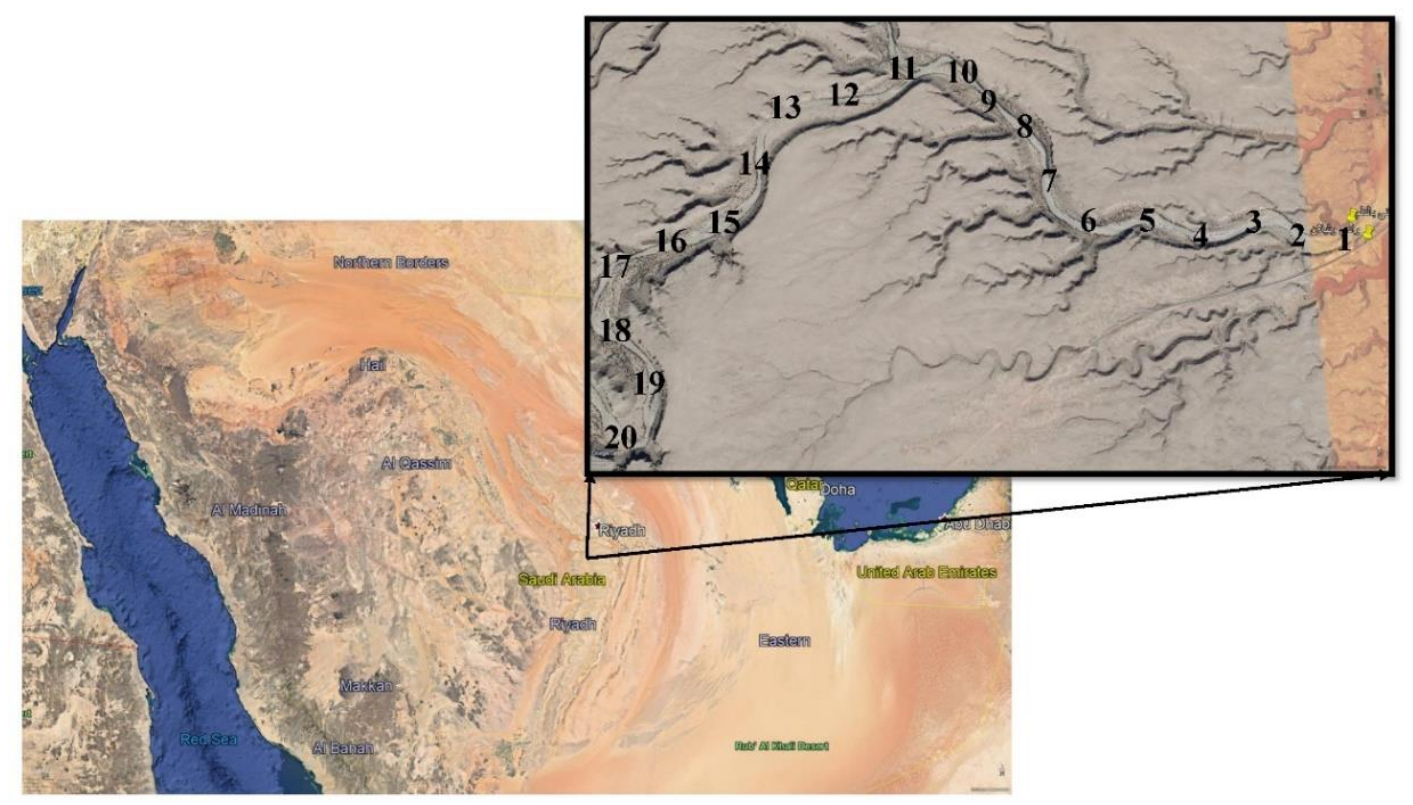

Figure 1. Study area map showing the whole map of Saudi Arabia with focus on the study area (Wadi Othylan). The numbers on Wadi Othylan map indicate the locations of the selected sample stands

\section{Soil analysis}

For soil analysis purpose, $50-\mathrm{cm}$ depth soil samples were collected using soil spades from the studied stands (3 replicates each) and pooled together in one composite sample. Hydrometer method was used to examine soil texture (Allen, 1989). Mass loss after ignition at $450{ }^{\circ} \mathrm{C}$ was used as indicator for total organic matter content. An amount of $100 \mathrm{~g}$ of air-dried soil were suspended in $500 \mathrm{ml}$ of distilled water to prepare the soil extract (1: 5). The extract was used for further chemical analysis. Soil $\mathrm{pH}$ and electrical conductivity (EC) was measured. Content of nutrient elements (N, P, K, Ca, Mg, Na and $\mathrm{Fe}$ ) in the soil were analyzed using Inductively Coupled Plasma Optical Emission Spectrometry (ICP MSEOS 6000 Series, ThermoFisher Scientific) method (Allen, 1989). 


\section{Data analysis}

Multivariate analysis using TWINSPAN software (Hill, 1979b) and detrended correspondence analysis (DCA) using DECORANA software (Hill, 1979a) were applied for the cover estimates calculated for all collected plants from the 22 studied stands. The relative cover $\left(p_{i}\right)$ of each stand was used to calculate Simpson index following the equation $C=\sum_{i=1}^{S} p_{i}^{2}$ as an indicator for the relative dominance concentration and Shannon-Wiener index following the equation $\widehat{H}=-\sum_{i=1}^{s} p_{i} \log p_{i}$ as an indicator for the relative evenness where $s$ is the total number of collected species (Pielou, 1975; Magurran, 1988). Pearson's simple linear correlation coefficient ( $r$ ) was used to examine the relationships among the ordination axes and the soil and community variables. The variation in the species diversity, stand traits and soil variables in relation to plant community were assessed via one-way analysis of variance using SPSS 18.0.

\section{Results}

\section{Floristic structure}

A total of 78 plant species belonging to 69 genera distributed in 27 families were collected from the studies stands (Appendix 1). As shown in Fig. 2, the most represented families in the study area were Compositae represented by 14 species (18\%), Poaceae represented by 10 species (13\%), Cruciferae represented by 7 species (9\%) and Leguminosae represented by 6 species (8\%). The most prominent life forms (Fig. 3a) were annual herbs (45\%), perennial herbs (30\%) and shrubs $(22 \%)$. On the other hand, the dominant chorotypes (Fig. 3b) were the Saharo-Arabian region (49\%) followed by the Saharo-Arabian-Irano-Turanian (13\%) and the Sahelian-Somali-Masai (8\%). Some rare species were identified e.g. Abutilon pannosum, Aristida adscensionis, and Trigonella hamosa. Two endangered species were identified in the study area, namely Astragalus sp. and Senecio sp.

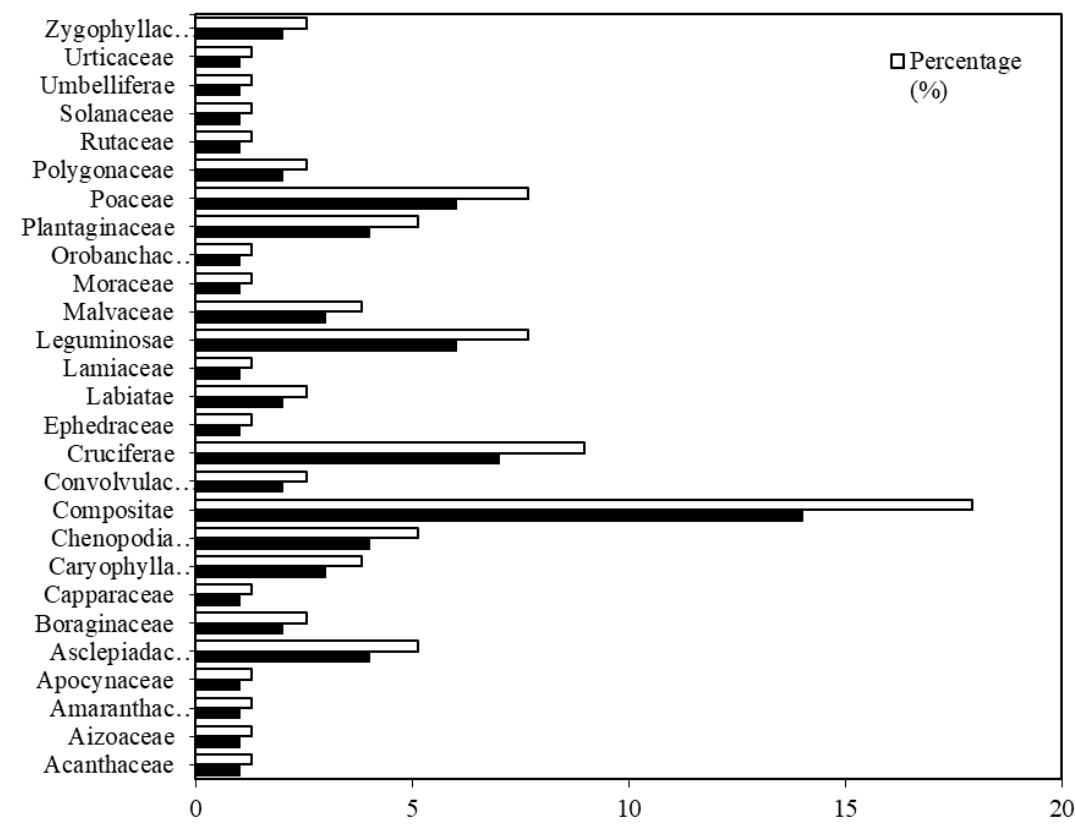

Figure 2. Families of the recorded species in Wadi Othylan 

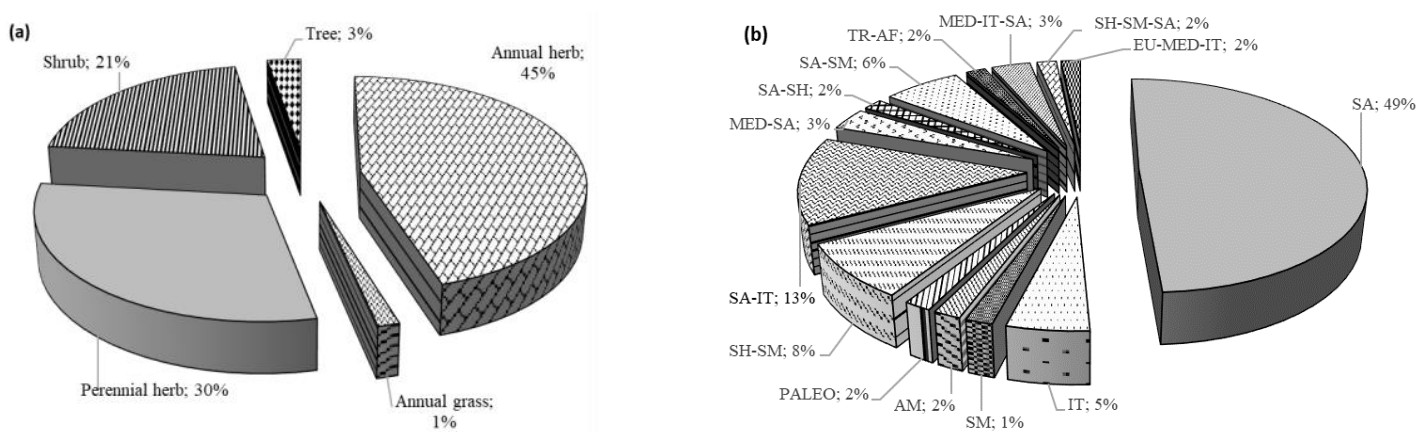

Figure 3. Life forms (a) and chorotypes (b) of the recorded species in Wadi Othylan (SA: Saharo-Arabian; SA-IT: Saharo-Arabian-Irano-Turanian; SH-SM: Sahelian-Somali-Masai; SA-

SM: Saharo-Arabian-Somali-Masai; Med-SA: Mediterranean-Saharo-Arabian; Med-IT-SA:

Mediterranean-Irano-Turanian-Saharo-Arabian; AM: American; SM: Somali-Masai; PALEO:

Paleotropics; SA-SH: Saharo-Arabian-Sahelian; TR-AF: Tropical African; SH-SM-SA:

Sahelian-Somali-Masai-Saharo-Arabian; EU-Med-IT: Euro-Siberian-Mediterranean-Irano-

Turanian)

\section{Multivariate analysis}

The dataset formed in this study consisted of 20 studied stands and 78 collected species. TWINSPAN analysis of this dataset generated a dendrogram divided it into four vegetation groups (plant communities) at the second level. Characterization and nomination of these groups were assigned based on the dominant and subdominant species in each group as follows: vegetation group (VG) I: Fagonia bruguieri-Haloxylon salicornicum, VG II: Acacia ehrenbergiana-Echinops spinosissima, VG III: Acacia ehrenbergiana-Acacia gerardii and VG IV: Acacia ehrenbergiana-Calotropis procera (Table 1). Further detrended correspondence (DCA) analysis confirmed the separation of these plant communities generated by TWINSPAN and reveals a great relationship between topographic aspects and environmental gradients in Wadi Othylan (Fig. 4a,b; Appendix 1).

Table 1. Different vegetation groups nominated in the study site

\begin{tabular}{|c|c|c|c|c|c|c|}
\hline \multirow{2}{*}{ Group } & \multicolumn{2}{|c|}{ Stand No } & \multirow{2}{*}{ Habitat (\%) } & \multirow{2}{*}{ Dominant species } & \multirow{2}{*}{$\mathbf{P} \%$} & \multirow{2}{*}{$\mathrm{C} \%$} \\
\hline & Stand & Total & & & & \\
\hline \multirow{3}{*}{ VG I } & \multirow{3}{*}{$\begin{array}{c}11,12,14 \\
15,16,17,19\end{array}$} & \multirow{3}{*}{7} & \multirow{3}{*}{$\begin{array}{c}\mathrm{A}=28.5^{*} \\
\mathrm{~B}=43 \\
\mathrm{C}=28.5\end{array}$} & Haloxylon salicornicum & 42.86 & 1.57 \\
\hline & & & & Fagonia bruguieri & 71.43 & 2.86 \\
\hline & & & & Rumex vesicarius & 71.43 & 1.71 \\
\hline \multirow{3}{*}{ VG II } & \multirow{3}{*}{$1,2,3,4$} & \multirow{3}{*}{4} & \multirow{3}{*}{$\begin{array}{l}\mathrm{A}=25 \\
\mathrm{~B}=50 \\
\mathrm{C}=25\end{array}$} & Acacia ehrenbergiana & 100 & 6.5 \\
\hline & & & & Echinops spinosissima & 100 & 7.5 \\
\hline & & & & Farsetia longisiliqua & 75 & 5 \\
\hline \multirow{3}{*}{ VG III } & \multirow{3}{*}{$\begin{array}{l}5,8,9,10 \\
13,18,20\end{array}$} & \multirow{3}{*}{7} & \multirow{3}{*}{$\begin{array}{c}\mathrm{A}=0 \\
\mathrm{~B}=14 \\
\mathrm{C}=86\end{array}$} & Acacia ehrenbergiana & 57.14 & 5.71 \\
\hline & & & & Acaia gerrardii & 42.86 & 5.43 \\
\hline & & & & Plantago ovate & 100 & 12.57 \\
\hline \multirow{3}{*}{ VG VI } & \multirow{3}{*}{6,7} & \multirow{3}{*}{2} & \multirow{3}{*}{$\begin{array}{c}\mathrm{A}=0 \\
\mathrm{~B}=0 \\
\mathrm{C}=100\end{array}$} & Acacia ehrenbergiana & 50 & 3 \\
\hline & & & & Calotropis procera & 50 & 4.5 \\
\hline & & & & Schismus barbatus & 100 & 4 \\
\hline
\end{tabular}

*A: Terrace, B: Slope, C: Wadi bed, P: presence (\%), C: cover (\%) 

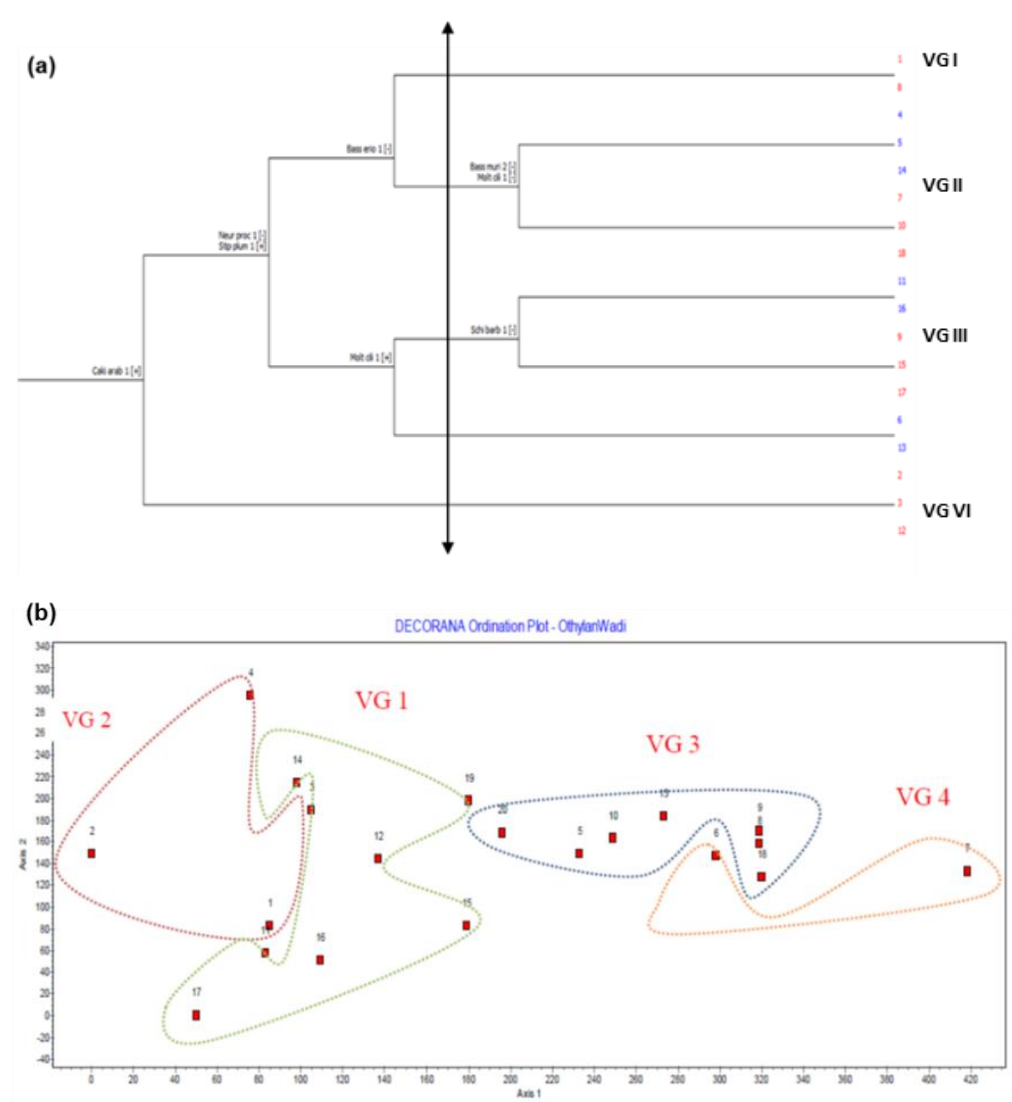

Figure 4. Relationships among the four plant communities as generated by TWINSPAN $(a)$ and DECORANA (b) software. VG I: Fagonia bruguieri-Haloxylon salicornicum, VG II: Acacia ehrenbergiana-Echinops spinosissima, VG III: Acacia ehrenbergiana-Acacia gerardii and VG IV: Acacia ehrenbergiana-Calotropis procera

\section{Soil characteristics, plant diversity and plant community relationships}

Table 2 shows that number of species was negatively correlated with $\mathrm{pH}$ of soil solution ( $r=-0.571, P \leq 0.01)$. Species richness had a negative correlation with $\mathrm{pH}$ of the soil solution $(r=-0.637, P \leq 0.01)$; however, it was positively correlated with soil $\mathrm{Na}$ content $(r=0.461, P \leq 0.05)$. Similarly, Shannon index had a strong negative correlation relationship with the soil solution $\mathrm{pH}(r=-0.650, P \leq 0.01)$. On the other hand, Simpson index showed a positive correlation with $\mathrm{pH}$ of soil solution $(r=0.481, P \leq 0.05)$.

Table 3 shows that the Acacia ehrenbergiana-Echinops spinosissima vegetation group (VG II) had the highest number of species (21.25), species cover $\left(73.00 \mathrm{~m}-100 \mathrm{~m}^{-1}\right)$ and species richness (4.72). Fagonia bruguieri-Haloxylon salicornicum vegetation group (VG I) showed the highest species evenness (0.93) with the lowest species richness (2.73). Acacia ehrenbergiana-Acacia gerardii vegetation group (VG III) showed the highest Simpson index (0.14) and the lowest species evenness (0.85). The habitats of Acacia ehrenbergiana-Calotropis procera community (VG VI) occupied the soil characterized by the highest sand content $(77.00 \%)$. On the other hand, the habitats of Fagonia bruguieri-Haloxylon salicornicum community (VG I) characterized by the highest silt $(24.86 \%)$ and organic matter $(10.61 \%)$ contents. Acacia ehrenbergiana-Echinops spinosissima community (VG II) occupied the habitats characterized by the highest soil clay content $(7.50 \%)$. 
Table 2. Pearson correlation coefficients between species diversity and soil characteristics

\begin{tabular}{|c|c|c|c|c|c|c|}
\hline Variable & $\begin{array}{c}\text { No. of } \\
\text { species }\end{array}$ & $\mid \begin{array}{c}\text { Species cover }(\mathrm{m}- \\
100 \mathrm{~m}^{-1)}\end{array}$ & $\begin{array}{l}\text { Species } \\
\text { richness }\end{array}$ & $\begin{array}{c}\text { Species } \\
\text { evenness }\end{array}$ & $\begin{array}{c}\text { Shannon } \\
\text { index }\end{array}$ & $\begin{array}{c}\text { Simpson } \\
\text { index }\end{array}$ \\
\hline \multicolumn{7}{|l|}{ Bulk soil (\%) } \\
\hline Sand & 0.22 & 0.276 & 0.158 & -0.374 & 0.103 & 0.26 \\
\hline Silt & -0.26 & -0.326 & -0.184 & 0.392 & -0.138 & -0.26 \\
\hline Clay & 0.02 & 0.023 & 0.006 & 0.207 & 0.09 & -0.204 \\
\hline $\mathbf{O M}$ & -0.244 & -0.28 & -0.204 & 0.391 & -0.113 & -0.22 \\
\hline \multicolumn{7}{|l|}{ Soil } \\
\hline $\mathrm{pH}$ & $-0.571^{* *}$ & -0.392 & $-0.637^{* *}$ & -0.148 & $-0.650^{* * *}$ & $0.481^{*}$ \\
\hline EC $(\mathbf{m S} / \mathbf{c m})$ & -0.114 & -0.166 & -0.083 & 0.214 & -0.03 & -0.124 \\
\hline \multicolumn{7}{|c|}{ Mineral content (ppm) } \\
\hline $\mathbf{N}$ & 0.011 & -0.153 & 0.116 & 0.336 & 0.144 & -0.35 \\
\hline $\mathbf{P}$ & -0.364 & -0.308 & -0.318 & 0.303 & -0.258 & -0.12 \\
\hline $\mathbf{K}$ & -0.183 & -0.193 & -0.164 & 0.197 & -0.105 & -0.077 \\
\hline Mg & -0.037 & -0.145 & 0.017 & 0.227 & 0.057 & -0.184 \\
\hline $\mathbf{C a}$ & -0.043 & -0.115 & -0.01 & 0.239 & 0.039 & -0.168 \\
\hline $\mathbf{F e}$ & -0.065 & -0.095 & -0.05 & 0.198 & 0.006 & -0.126 \\
\hline $\mathbf{N a}$ & 0.375 & 0.133 & $0.461^{*}$ & 0.142 & 0.42 & -0.315 \\
\hline
\end{tabular}

*: $\mathrm{P} \leq 0.05,{ }^{* *}: \mathrm{P} \leq 0.01$

Table 3. Soil variables and diversity indices of different vegetation groups in the study site. Values are shown as mean \pm standard deviation

\begin{tabular}{c|c|c|c|c|c|c}
\hline VG $^{*}$ & VG 1 & VG 2 & VG 3 & VG 4 & Total & F-Value \\
\hline \multicolumn{7}{c}{ Diversity indices } \\
\hline Number & $9.14 \pm 1.21$ & $21.25 \pm 4.11$ & $14.14 \pm 5.96$ & $17.00 \pm 1.00$ & $14.24 \pm 5.81$ & $8.286^{* * *}$ \\
Cover & $20.29 \pm 5.15$ & $73.00 \pm 15.60$ & $50.29 \pm 30.87$ & $36.33 \pm 1.53$ & $42.62 \pm 26.76$ & $6.61^{* *}$ \\
Richness & $2.73 \pm 0.35$ & $4.72 \pm 0.78$ & $3.43 \pm 0.97$ & $4.45 \pm 0.23$ & $3.59 \pm 1.02$ & $8.67^{* * *}$ \\
Evenness & $0.93 \pm 0.06$ & $0.92 \pm 0.03$ & $0.85 \pm 0.08$ & $0.91 \pm 0.00$ & $0.90 \pm 0.07$ & 2.76 \\
Shannon & $0.89 \pm 0.09$ & $1.22 \pm 0.10$ & $0.94 \pm 0.17$ & $1.11 \pm 0.02$ & $1.00 \pm 0.17$ & $7.72^{* *}$ \\
Simpson & $0.11 \pm 0.06$ & $0.06 \pm 0.02$ & $0.14 \pm 0.05$ & $0.08 \pm 0.00$ & $0.10 \pm 0.05$ & 2.72 \\
\hline \multicolumn{7}{|c}{ Soil bulk(\%) } \\
\hline Sand & $68.00 \pm 11.89$ & $74.00 \pm 8.16$ & $71.71 \pm 9.62$ & $77.00 \pm 13.00$ & $71.67 \pm 10.35$ & 0.59 \\
Silt & $24.86 \pm 10.38$ & $18.50 \pm 5.74$ & $20.86 \pm 8.40$ & $17.00 \pm 11.00$ & $21.19 \pm 8.91$ & 0.71 \\
Clay & $7.14 \pm 1.95$ & $7.50 \pm 2.52$ & $7.43 \pm 1.51$ & $6.00 \pm 2.00$ & $7.14 \pm 1.85$ & 0.45 \\
OM & $10.61 \pm 8.34$ & $6.35 \pm 3.41$ & $3.89 \pm 2.17$ & $2.43 \pm 0.18$ & $6.39 \pm 5.90$ & 2.54 \\
\hline \multicolumn{7}{c}{ Soil } \\
\hline pH & $8.10 \pm 0.16$ & $7.87 \pm 0.05$ & $8.04 \pm 0.13$ & $7.74 \pm 0.34$ & $7.98 \pm 0.20$ & $3.97^{*}$ \\
EC & $2.35 \pm 5.66$ & $0.83 \pm 1.41$ & $0.15 \pm 0.04$ & $1.21 \pm 1.10$ & $1.16 \pm 3.30$ & 0.50 \\
\hline
\end{tabular}

*VG: vegetation group, VG I: Fagonia bruguieri-Haloxylon salicornicum, VG II: Acacia ehrenbergianaEchinops spinosissima, VG III: Acacia ehrenbergiana-Acacia gerardii and VG IV: Acacia ehrenbergiana-Calotropis procera. ${ }^{*}: P \leq 0.05,{ }^{* *}: P \leq 0.01,{ }^{* * *}: P \leq 0.001$ 


\section{Discussion}

Topography and land forms significantly influence the growth, existence and distribution of different plant life forms in arid and semi-arid regions (Kassas and Girgis, 1964; Zohary, 1973; Shaltout et al., 2010) such the protected area of wadi Othylan; the site under study. The central region dominated mainly be the Najd plateau is characterized by the existence of different wadi (valley) habitats (Mandaville, 1990) including wadi Othylan. Wadi Othylan protected area is one of the richest wadis in vegetation and floristic diversity. The results obtained in this study indicated that the dominant life form in the study site are annual herbs (45\%) and perennial herbs (30\%) followed by shrubs $(20.5 \%)$ and trees $(2.74 \%)$. These results are comparable to the results found by El-Sheikh et al. (2019) as the annual herbs and perennials or subshrubs represented $~ 96 \%$ of plants identified in Harrat Al-Harrah protectorate, Northern Saudi Arabia. In another study, ElSheikh et al. (2013) found that annual herbs and perennials dominated the identified species in Thumamah Nature Park. Like wise, perennials and annuals dominated the 128 different species identified in wadi Huraimla, Central Saudi Arabia (Alatar et al., 2015). The dominance of annual herbs could be attributed to the abundance of water during rainy seasons supporting the growth of such plants (Schulz and Whitney, 1986; Shaltout and Mady, 1996; Hosni and Hegazy, 1996; Shaltout et al., 2010). However, this water is not adequate to support the growth of perennial herbs; therefore, the existence of such plants may be due to their adaptation to the harsh conditions exist in the study site (Alatar et al., 2012).

The rarity or complete absence of synanthropic species (e.g. Prosopis juliflora, Salsola imbricate, Tamarix nilotica, Bassia eriophora and Cynodon dactylon) in wadi Othylan indicates low severity of human impact. Indeed, this is clearly true as wadi Othylan is considered as a protected area since more than 30 years ago. Furthermore, the presence of some rare and endangered plants in the study area is considered as another indicator for lower human impact (Taia and El-Ghanem, 2001).

The composition of vegetation life forms and chorotype in the study area showed a typical pattern of the desert flora dominated by xerophytes and chamaephytes. The same pattern of vegetation was observed in different desert habitats among different parts of Saudi Arabia (Collenette, 1985, 1998, 1999; El-Demerdash et al., 1994; Chaudhary, 2001; Al-Turki and Al-Olayan, 2003; Fahmy and Hassan, 2005; El-Ghanim et al., 2010). In either wadi or protected areas in Saudi Arabia, the previous studies showed that xerophytes and chamaephytes are the dominant life forms and chorotypes (El-Sheikh et al., 2013; Alatar et al., 2015; El-Sheikh et al., 2019). In general, there is a great correlation between the plants' life forms and topography of their habitats (Kassas and Girgis, 1964; Zohary, 1973; Shaltout et al., 2010). In this study, the dominant plant chorotype was the Saharo Arabian (49\%). The species of Saharo Arabian chorotype are distributed only along the central strip of Saudi Arabia and are more abundant in habitats providing protection and/or habitats characterized by more favorable micro-climate conditions (Zohary, 1973; Hegazy et al., 1998; El-Ghanim et al., 2010; Ghazanfar and Fisher, 2013). The central region of Saudi Arabia covers a wide range of bioclimatic zones and characterized by the existence of different rocky habitats that supports several other chorotypes which were found in the study area beside the Saharo Arabian species e.g. Saharo Arabian Irano Turanian (13\%) and Sahelian Somali Masai (8\%). Furthermore, the Central region of Saudi Arabia covers the transition zone between the Somalia Masai zone and the Afromontane archipelago-like center (Zohary, 1973; Mandaville, 1990; White and Léonard, 1990). Some parts of the central region cover the Mediterranean and 
Irano Turanian zones (Hegazy et al., 1998; Alfarhan, 1999; Ghazanfar and Osborne, 2010). Species of both zones were found in this study.

The results of correlation analysis in this study showed a positive relationship between species diversity (evenness) and soil organic matter content. In contrast, species diversity was negatively correlated with soil solution $\mathrm{pH}$ and EC. Other studies reported the same pattern of correlation in desert habitats of Saudi Arabia (El-Demerdash et al., 1994; Abbadi and El-Sheikh, 2002; El-Sheikh et al., 2010, 2013, 2018).

\section{Conclusion}

The current study examined the floristic structure and vegetation diversity in the protected area of Wadi Othaylan, Saudi Arabia. The results howed that this area characterized by high plant diversity and various structure with plants classified into four different vegetation groups. Some rare and endangered plants were found in the studied area indicating the role of protection in keeping vegetation diversity. The limitation of this study were mostly relating to the high danger slopes with high number of snakes and scorpions that hinders the study of some locations, in addition to that based on the sampling areas, adding a complete list of the present species is impossible. Further studies to examine the vegetation diversity of this area and similar protected areas in Saudi Arabia are recommended.

Acknowledgements. This scientific paper contains studies and research results supported by King Abdulaziz City for Science and Technology grant no. (1-17-01-001-0034).

\section{REFERENCES}

[1] Abbadi, G. A., El-Sheikh, M. A. (2002): Vegetation analysis of Failaka Island (Kuwait). Journal of Arid Environments 50: 153-165.

[2] Al-Nafie, A. H. (2008): Phytogeography of Saudi Arabia. - Saudi Journal of Biological Sciences 15: 159-176.

[3] Al-Turki, T., Al-Olayan, H. (2003): Contribution to the flora of Saudi Arabia: Hail region. - Saudi Journal of Biological Sciences 10: 190-222.

[4] Alatar, A., El-Sheikh, M. A., Thomas, J. (2012): Vegetation analysis of Wadi Al-Jufair, a hyper-arid region in Najd, Saudi Arabia. - Saudi Journal of Biological Sciences 19: 43-54.

[5] Alatar, A. A., El-Sheikh, M. A. R., Thomas, J., Hegazy, A. K., El Adawy, H. A. (2015): Vegetation, Floristic Diversity, and Size-Classes of Acacia gerrardii in an Arid Wadi Ecosystem. - Arid Land Research and Management 29: 335-359.

[6] Alfarhan, A. (1999): A phytogeographical analysis of the floristic elements in Saudi Arabia. - Pakistan Journal of Biological Sciences (Pakistan) 2: 702-711.

[7] Alfarhan, A. (2001): A floristic account on Raudhat Khuraim Central Province Saudi Arabia. - Saudi Journal of Biological Sciences 8: 80-103.

[8] Allen, S. E. (1989): Chemical analysis of ecological materials. - Blackwell Scientific, Oxford.

[9] Batanouny, K. H. (1987): Current knowledge of plant ecology in the Arab Gulf Countries. - CATENA 14: 291-315.

[10] Canfield, R. H. (1941): Application of the Line Interception Method in Sampling Range Vegetation. - Journal of Forestry 39: 388-394.

[11] Chaudhary, S. A. (2001): Flora of the Kingdom of Saudi Arabia. - Ministry of Agriculture and Water, Riyadh. 
[12] Collenette, S. (1985): An illustrated guide to the flowers of Saudi Arabia. - Scorpion publishing Ltd, Riyadh.

[13] Collenette, S. (1998): A Checklist of Botanical Species in Saudi Arabia. - International Asclepiad Society, West Sussex (UK).

[14] Collenette, S. (1999): Wildflowers of Saudi Arabia. - National Commission for Wildlife Conservation and Development (NCWCD), Riyadh.

[15] El-Demerdash, M., Hegazy, A., Zilay, A. (1994): Distribution of the plant communities in Tihamah coastal plains of Jazan region, Saudi Arabia. - Vegetatio 112: 141-151.

[16] El-Ghanim, W. M., Hassan, L. M., Galal, T. M., Badr, A. (2010): Floristic composition and vegetation analysis in Hail region north of central Saudi Arabia. - Saudi Journal of Biological Sciences 17: 119-128.

[17] El-Sheikh, M. A., Abbadi, G. A., Bianco, P. M. (2010): Vegetation ecology of phytogenic hillocks (nabkhas) in coastal habitats of Jal Az-Zor National Park, Kuwait: Role of patches and edaphic factors. - Flora-Morphology, Distribution, Functional Ecology of Plants 205: 832-840.

[18] El-Sheikh, M. A., Thomas, J., Alatar, A. A., Hegazy, A. K., Abbady, G. A., Alfarhan, A. H., Okla, M. I. (2013): Vegetation of Thumamah Nature Park: a managed arid land site in Saudi Arabia. - Rendiconti Lincei 24: 349-367.

[19] El-Sheikh, M. A., Al-Oteiby, S. A., Alfarhan, A. H., Barcelo, D., Picó, Y., Alatar, A. A., Javed, S. B., Eid, E. M. (2018): Distribution of soil organic carbon in Wadi Al-Thulaima, Saudi Arabia: A hyper-arid habitat altered by wastewater reuse. - CATENA 170: 266-271.

[20] El-Sheikh, M. A., Al-Shehri, M. A., Alfarhan, A. H., Alatar, A. A., Rajakrishnan, R., AlRowaily, S. L. (2019): Threatened Prunus arabica in an ancient volcanic protected area of Saudi Arabia: Floristic diversity and plant associations. - Saudi Journal of Biological Sciences 26: 325-333.

[21] Fahmy, A., Hassan, L. (2005): Plant diversity of wadi el Ghayl, Aseer Mountains, Saudi Arabia. - Egyptian Journal of Desert Research 55: 39-52.

[22] Ghazanfar, S. A., Osborne, J. (2010): Conservation through restoration: study of a degraded gravel plain in South Eastern Arabia. - Pakistan Journal of Botany 42: 193-204.

[23] Ghazanfar, S. A., Fisher, M. (2013): Vegetation of the Arabian Peninsula. - Springer Science \& Business Media, London.

[24] Hegazy, A. K., El-Demerdash, M. A., Hosni, H. A. (1998): Vegetation, species diversity and floristic relations along an altitudinal gradient in south-west Saudi Arabia. - Journal of Arid Environments 38: 3-13.

[25] Hill, M. O. (1979a): DECORANA: A FORTRAN Program for Detrended Correspondence Analysis and Reciprocal Averaging. - Section of Ecology and Systematics, Cornell University, NY.

[26] Hill, M. O. (1979b): TWINSPAN: A FORTRAN Program for Arranging Multivariate Data in an Ordered Two-way Table by Classification of the Individuals and Attributes. - Section of Ecology and Systematics, Cornell University, NY.

[27] Hosni, H. A., Hegazy, A. K. (1996): Contribution to the flora of Asir, Saudi Arabia. Candollea 51: 169-202.

[28] Kassas, M., Girgis, W. A. (1964): Habitat and Plant Communities in the Egyptian Desert: V. The Limestone Plateau. - Journal of Ecology 52: 107-119.

[29] Magurran, A. E. (1988): Diversity indices and species abundance models. - In: Magurran, A. E. (ed.) Ecological Diversity and Its Measurement. Dordrecht: Springer Netherlands.

[30] Mandaville, J. P. (1990): Flora of Eastern Saudi Arabia. - Routledge, London.

[31] Pielou, E. C. (1975): Ecological diversity. - Wiley, NY.

[32] Schulz, E., Whitney, J. (1986): Vegetation in north-central Saudi Arabia. - Journal of arid environments 10: 175-186.

[33] Shaltout, K. H., Mady, M. A. (1996): Analysis of raudhas vegetation in central Saudi Arabia. - Journal of Arid Environments 34: 441-454. 
[34] Shaltout, K. H., Sheded, M. G., Salem, A. I. (2010): Vegetation spatial heterogeneity in a hyper arid Biosphere Reserve area in north Africa. - Acta Botanica Croatica 69: 31-46.

[35] Shelter, S. G., Skog, L. E. (1978): A provisional checklist of species for flora of North America. - Missouri Botanical Garden, St. Louis, Missouri.

[36] Taia, W., El-Ghanem, W. (2001): City vegetation analysis of three habitats at El-Riyadh. - Bulletin of Pure and Applied Sciences B 20: 53-65.

[37] White, F., Léonard, J. (1990): Phytogeographical links between Africa and southwest Asia. - Flora et Vegetation Mundi 9: 229-246.

[38] Zohary, M. (1973): Geobotanical foundations of the Middle East. - Gustav Fischer Verlag, Stuttgart.

\section{APPENDIX}

Appendix 1. List of collected plants and their life forms, chorotype, and coverage

\begin{tabular}{|c|c|c|c|c|c|c|c|c|c|c|}
\hline \multirow{2}{*}{ Species } & \multirow{2}{*}{ Life form } & \multirow{2}{*}{ Chorotype* } & \multicolumn{2}{|c|}{ VG I } & \multicolumn{2}{|c|}{ VG II } & \multicolumn{2}{|c|}{ VG III } & \multicolumn{2}{|c|}{ VG IV } \\
\hline & & & $\mathrm{C} \%$ & $\mathbf{P \%}$ & $\mathrm{C} \%$ & $\mathbf{P \%}$ & $\mathrm{C} \%$ & $\mathbf{P \%}$ & $\mathrm{C \%}$ & $\mathbf{P \%}$ \\
\hline Abutilon pannosum ${ }^{l}$ & Shrub & & 0.71 & 28.57 & 0.00 & 0.00 & 0.00 & 0.00 & 0.00 & 0.00 \\
\hline Acacia ehrenbergiana & Shrub & SH-SM & 0.00 & 0.00 & 6.50 & 100.00 & 5.71 & 57.14 & 3.00 & 50.00 \\
\hline Acaia gerrardii & Tree & SH-SM & 0.00 & 0.00 & 0.00 & 0.00 & 5.43 & 42.86 & 0.00 & 0.00 \\
\hline Achillea fragrantissima ${ }^{l}$ & Perennial herb & & 0.00 & 0.00 & 2.00 & 75.00 & 0.00 & 0.00 & 0.00 & 0.00 \\
\hline Aerva javanica ${ }^{l}$ & Perennial herb & Subshrub & 0.00 & 0.00 & 1.25 & 50.00 & 0.00 & 0.00 & 0.00 & 0.00 \\
\hline Aizoon canariense ${ }^{1}$ & Annual herb & SA & 0.00 & 0.00 & 0.00 & 0.00 & 0.14 & 14.29 & 0.00 & 0.00 \\
\hline Anisosciadium lanatum ${ }^{l}$ & Annual herb & SA & 0.00 & 0.00 & 0.00 & 0.00 & 0.00 & 0.00 & 0.50 & 50.00 \\
\hline Anvillea garcinia ${ }^{l}$ & Shrub & SA & 0.00 & 0.00 & 2.00 & 50.00 & 0.00 & 0.00 & 0.00 & 0.00 \\
\hline Aristida adscensionis ${ }^{I}$ & Perennial grass & MED-IT-SA & 0.00 & 0.00 & 1.75 & 50.00 & 0.00 & 0.00 & 0.00 & 0.00 \\
\hline Astragalus sp. ${ }^{2}$ & Annual herb & IT & 0.00 & 0.00 & 0.00 & 0.00 & 0.14 & 14.29 & 0.00 & 0.00 \\
\hline Bassia eriophora $^{l}$ & Annual herb & SA-IT & 0.00 & 0.00 & 0.00 & 0.00 & 0.57 & 42.86 & 0.00 & 0.00 \\
\hline Bassia muricata & Annual herb & SA-IT & 0.00 & 0.00 & 0.00 & 0.00 & 0.29 & 14.29 & 1.00 & 50.00 \\
\hline Blepharis ciliaris & Herb & SA-IT & 0.00 & 0.00 & 0.50 & 50.00 & 0.00 & 0.00 & 0.00 & 0.00 \\
\hline Brachypodium distachyon & Annual herb & & 0.00 & 0.00 & 0.50 & 25.00 & 0.00 & 0.00 & 1.00 & 50.00 \\
\hline Calendula arvensis & Annual herb & & 1.00 & 42.86 & 0.00 & 0.00 & 0.14 & 14.29 & 0.00 & 0.00 \\
\hline Calotropis procera & Shrub & SM & 0.00 & 0.00 & 0.00 & 0.00 & 0.00 & 0.00 & 4.50 & 50.00 \\
\hline artilaginea & & & & 0.00 & & & 0.00 & & 0.00 & 0.00 \\
\hline Cenchrus ciliaris & Perennial grass & SA & 0.14 & 14.29 & 1.25 & 75.00 & 2.14 & 14.29 & 0.00 & 0.00 \\
\hline Chenopodium murale & Annual herb & PALEO & 0.00 & 0.00 & 0.00 & 0.00 & 1.00 & 28.57 & 0.00 & 0.00 \\
\hline Cistanche tubulosa & Annual herb & SA-IT & 0.00 & 0.00 & & 0.00 & 0.00 & & 0.50 & 50.00 \\
\hline Convolvulus pilosellifolius & Perennial herb & IT & 0.00 & 0.00 & 1.00 & 50.00 & 0.00 & 0.00 & 0.00 & 0.00 \\
\hline Cuscuta planiflora & Annual herb & $\mathrm{AM}$ & 0.29 & 14.29 & 1.25 & 75.00 & 1.14 & 42.86 & 0.00 & 0.00 \\
\hline Diplotaxis harra & Perennial herb & SH-SM & 1.43 & 85.71 & 2.00 & 100.00 & 0.57 & 42.86 & 0.00 & 0.00 \\
\hline Echinops spinosissima & Shrub & SA & 0.29 & 14.29 & 7.50 & 100.00 & 0.57 & 14.29 & 0.00 & 0.00 \\
\hline Emex spinosa & Annual herb & MED-SA & 0.14 & 14.29 & 0.00 & 0.00 & 0.14 & 14.29 & 0.50 & 50.00 \\
\hline Ephedra foliata & & SH-SM & 0.00 & 0.00 & 1.00 & 25.00 & 0.29 & 14.29 & 0.00 & 0.00 \\
\hline Eremobium lineare & Annual herb & SA & 0.00 & 0.00 & 0.00 & 0.00 & 0.00 & 0.00 & 0.50 & 50.00 \\
\hline Erodium laciniatum & Annual herb & MED-IT-SA & 0.00 & 0.00 & 0.00 & 0.00 & 0.00 & 0.00 & 0.50 & 50.00 \\
\hline Fagonia bruguieri & Perennial shrub & SA & 2.86 & 71.43 & 3.00 & 50.00 & 2.57 & 85.71 & 0.50 & 50.00 \\
\hline Farsetia longisiliqua & Perennial shrub & SA & 0.57 & 28.57 & 5.00 & 75.00 & 1.86 & 85.71 & 0.50 & 50.00 \\
\hline Ficus palmata & Tree & & 0.00 & 0.00 & 0.25 & 25.00 & 0.00 & 0.00 & 0.00 & 0.00 \\
\hline Forsskaolea tenacissima & Perennial herb & & 1.00 & 42.86 & 1.50 & 50.00 & 0.14 & 14.29 & 0.00 & 0.00 \\
\hline Gymnocarpos decander & Perennial herb & SA & 0.00 & 0.00 & 0.25 & 25.00 & 0.00 & 0.00 & 0.00 & 0.00 \\
\hline Haloxylon salicornicum & Shrub & SA & 1.57 & 42.86 & 2.50 & 75.00 & 0.57 & 14.29 & 1.50 & 100.00 \\
\hline Haplophyllum tuberculatum & Perennial herb & IT & 0.00 & 0.00 & 0.00 & 0.00 & 0.57 & 28.57 & 0.00 & 0.00 \\
\hline Heliotropium bacciferum & Perennial herb & SA-SH & 0.00 & 0.00 & 0.00 & 0.00 & 0.86 & 57.14 & 2.00 & 50.00 \\
\hline
\end{tabular}




\begin{tabular}{|c|c|c|c|c|c|c|c|c|c|c|}
\hline \multirow{2}{*}{ Species } & \multirow{2}{*}{ Life form } & \multirow{2}{*}{ Chorotype* } & \multicolumn{2}{|c|}{ VG I } & \multicolumn{2}{|c|}{ VG II } & \multicolumn{2}{|c|}{ VG III } & \multicolumn{2}{|c|}{ VG IV } \\
\hline & & & $\mathrm{C} \%$ & $\mathbf{P \%}$ & $\mathrm{C} \%$ & $\mathbf{P \%}$ & $\mathrm{C} \%$ & $\mathbf{P \%}$ & $\mathrm{C} \%$ & $\mathbf{P \%}$ \\
\hline Hibiscus micranthus $^{l}$ & Shrub & & 0.00 & 0.00 & 2.75 & 75.00 & 0.00 & 0.00 & 0.00 & 0.00 \\
\hline Hyparrhenia hirta 1 & Perennial grass & SA & 0.00 & 0.00 & 0.50 & 25.00 & 0.00 & 0.00 & 0.00 & 0.00 \\
\hline Launaea angustifolia & Herb & SA & 0.71 & 42.86 & 1.00 & 50.00 & 0.57 & 28.57 & 0.00 & 0.00 \\
\hline Launaea mucronata & Annual herb & SA & 0.00 & 0.00 & 0.00 & 0.00 & 0.57 & 42.86 & 0.00 & 0.00 \\
\hline Leptadenia pyrotechnica & Shrub & SA-SM & 0.00 & 0.00 & 0.75 & 25.00 & 0.00 & 0.00 & 0.00 & 0.00 \\
\hline Lycium shawii & Shrub & SA & 0.86 & 42.86 & 3.00 & 75.00 & 0.00 & 0.00 & 0.00 & 0.00 \\
\hline Malva parviflora & Annual herb & MED-SA & 1.43 & 57.14 & 1.25 & 50.00 & 1.00 & 28.57 & 2.00 & 100.00 \\
\hline Medicago laciniata & Annual herb & SA & 0.14 & 14.29 & 0.00 & 0.00 & 0.00 & 0.00 & 0.00 & 0.00 \\
\hline Morettia parviflora & Perennial herb & SA & 0.00 & 0.00 & 0.00 & 0.00 & 0.29 & 14.29 & 0.00 & 0.00 \\
\hline Notoceras bicorne & Annual herb & & 0.00 & 0.00 & 0.00 & 0.00 & 0.29 & 14.29 & 1.00 & 100.00 \\
\hline Panicum turgidum & Perennial grass & SH-SM-SA & 0.00 & 0.00 & 0.50 & 25.00 & 0.00 & 0.00 & 0.50 & 50.00 \\
\hline Pennisetum divisum & Perennial grass & $\mathrm{SA}$ & 0.00 & 0.00 & 2.00 & 25.00 & 0.00 & 0.00 & 0.00 & 0.00 \\
\hline Pergularia tor & Perennial herb & SA & & 0.00 & 0.00 & 0.00 & 0.14 & 14.29 & 0.00 & 0.00 \\
\hline Periploca aphylla & Shrub & TR-AF & 0.00 & 0.00 & 3.00 & 50.00 & 0.00 & 0.00 & 0.00 & 0.00 \\
\hline Picris babylonica & Annual herb & SA & 0.00 & 0.00 & 0.00 & 0.00 & 1.14 & 57.14 & 0.00 & 0.00 \\
\hline Plantago ample & & SA & 0.71 & 28.57 & 0.00 & 0.00 & 0.00 & 0.00 & 0.00 & 0.00 \\
\hline Plantago boissieri & Annual herb & SA & 0.00 & 0.00 & 0.00 & 0.00 & 0.57 & 14.29 & 0.50 & 50.00 \\
\hline Plantago ciliata & Annual herb & SA & 0.00 & 0.00 & 0.00 & 0.00 & 0.57 & 28.57 & 0.50 & 50.00 \\
\hline Plantago ovata & Anuual herb & & 0.00 & 0.00 & 0.25 & 25.00 & 12.57 & 100.00 & 3.00 & 50.00 \\
\hline Pulicari & Shrub & SA-IT & 0.00 & 0.00 & 1.50 & 50.00 & 0.29 & 14.29 & 0.00 & 0.00 \\
\hline Pulicaria undulata & Shrub & SA-SM & 0.00 & 0.00 & 0.50 & 25.00 & 0.00 & 0.00 & 1.00 & 50.00 \\
\hline Reichardia tingitana & Annual herb & & 0.00 & 0.00 & 0.25 & 25.00 & 0.00 & 0.00 & 0.00 & 0.00 \\
\hline Rhante & Perennial herb & SA & 0.00 & 0.00 & 1.50 & 25.00 & 0.00 & 0.00 & 0.00 & 0.00 \\
\hline$R h a$ & Perennial herb & SA & 0.00 & 0.00 & 0.00 & 0.00 & 0.71 & 42.86 & 1.50 & 50.00 \\
\hline & & SA & 1.71 & 71.43 & 4.50 & 100.00 & 0.86 & 57.14 & 0.00 & 0.00 \\
\hline Salvia aegyptiaca & Perennial herb & & 0.29 & 14.29 & 0.00 & 0.00 & 0.14 & 14.29 & 0.00 & 0.00 \\
\hline & Perennial herb & SA & 0.00 & 0.00 & 1.25 & 50.00 & 0.00 & 0.00 & 0.00 & 0.00 \\
\hline & & SA & 0.57 & 42.86 & 0.00 & 0.00 & 0.71 & 42.86 & 1.50 & 100.00 \\
\hline Schismus barbatus & Annual grass & SA-IT & 0.00 & 0.00 & 0.00 & 0.00 & 0.00 & 0.00 & 4.00 & 100.00 \\
\hline Sclerocephalus arabicus & Perennial herb & SA & 0.57 & 14.29 & 0.00 & 0.00 & 0.14 & 14.29 & 0.00 & 0.00 \\
\hline & & & 1.14 & 71.43 & 2.00 & 50.00 & 0.29 & 28.57 & 0.50 & 50.00 \\
\hline Senecio sp. ${ }^{2}$ & Annual herb & & 0.00 & 0.00 & 1.25 & 25.00 & 0.00 & 0.00 & 0.00 & 0.00 \\
\hline italica & Shrub & SH-SM & 0.14 & 14.29 & 0.00 & 0.00 & 0.14 & 14.29 & 0.00 & 0.00 \\
\hline Sisymbrium irio & Anuual herb & & 0.57 & 42.86 & 1.25 & 75.00 & 1.71 & 71.43 & 1.00 & 50.00 \\
\hline Spergula fallax & & & 0.00 & 0.00 & 0.00 & 0.00 & 0.14 & 14.29 & 2.00 & 100.00 \\
\hline Stipa capensis & Anuual herb & SA-SM & 0.43 & 28.57 & 0.25 & 25.00 & 0.43 & 14.29 & 0.50 & 50.00 \\
\hline Tetrapogon villosus & Perennial herb & & 0.00 & 0.00 & 0.50 & 25.00 & 0.29 & 14.29 & 0.00 & 0.00 \\
\hline Teucrium polium & Perennial herb & SA-IT & 0.00 & 0.00 & 0.00 & 0.00 & 0.43 & 14.29 & 0.00 & 0.00 \\
\hline Tribulus terrestris & Annual herb & EU-MED-IT & 0.14 & 14.29 & 0.00 & 0.00 & 0.14 & 14.29 & 0.00 & 0.00 \\
\hline Trichodesma africanum & Perennial herb & $\mathrm{SA}$ & 0.86 & 14.29 & 1.25 & 75.00 & 0.14 & 14.29 & 0.00 & 0.00 \\
\hline Trigonella hamosa ${ }^{l}$ & & SA & 0.00 & 0.00 & 0.00 & 0.00 & 0.00 & 0.00 & 0.50 & 50.00 \\
\hline ripleurospermum auriculatum & Annual herb & SA-SM & 0.00 & 0.00 & 0.00 & 0.00 & 1.14 & 28.57 & 0.00 & 0.00 \\
\hline
\end{tabular}

${ }^{1}$ rare species, ${ }^{2}$ endangered species, ${ }^{*}$ SA: Saharo-Arabian; SA-IT: Saharo-Arabian-Irano-Turanian; SHSM: Sahelian-Somali-Masai; SA-SM: Saharo-Arabian-Somali-Masai; Med-SA: Mediterranean- SaharoArabian; Med-IT-SA: Mediterranean-Irano-Turanian-Saharo-Arabian; AM: American; SM: SomaliMasai; PALEO: Paleotropics; SA-SH: Saharo-Arabian- Sahelian; TR-AF: Tropical African; SH-SM-SA: Sahelian-Somali-Masai-Saharo-Arabian; EU-Med-IT: Euro-Siberian-Mediterranean-Irano-Turanian 